\title{
EL ARTE DE NO ENSEÑAR A ESCRIBIR
}

\section{Eduardo Parra Ramírez ${ }^{1}$}

Me enorgullece haber sido convidado a este simposio por la relevancia de la institución que lo convoca y la cualidad de las personas que a él concurren; pido perdón si las siguientes consideraciones no tienen un carácter estrictamente académico, ya que fueron concebidas desde la vocación de poetizar la vocación. Habida cuenta de mi insolvencia teórica, también pido una suspención de expectativas. He perdido la esperanza de enseñar algo. Resígnense a no aprender nada en los próximos minutos. Si mis alumnos pueden sostener esta misma resignación semestres enteros, media hora ustedes pueden concedeérmela.

"Todo lo que pueda ser dicho, que se diga en prosa, para la poesía reservamos lo innombrable."

S. Mallarmé

Formo parte de un proyecto educativo cuyo objetivo principal es iniciar a jóvenes creadores en la escritura literaria. Presido una escuela de escritores, si tal cosa es posible. Quiero decir, si es posible una escuela de escritores y si es posible presidirla. Diré que una de sus peculiaridades es que los alumnos se resisten enérgicamente a egresar.

Con frecuencia me preguntan si de verdad se puede enseñar a escribir o al menos aconsejar a un escritor en ciernes. En vez de responder lo que pienso, que el escritor verdadero ha de ser lo suficientemente insumiso como para no atender

\footnotetext{
${ }^{1}$ Escuela Mexicana de Escritores

RAMÍREZ, Eduardo Parra. El arte de no enseñar a escribir. Revista Sul-Americana de
} Filosofia e Educação. Número 23: nov/2014-abr/2015, p. 387-397. 
consejo o precepto, contesto lo obvio: el talento no se contrae ni puede garantizarse, la vocación no es una adquisición. Entonces, lo que se puede colectivizar e incluso escolarizar es el espacio para pensar la literatura y sus conocimientos subsidiarios, la técnica, el oficio, la guía en un mundo al que, en principio, no pertenecemos ni nos pertenece. Lo otro es individual. Las más grandes gestas se libran en la intimidad personal: se conquista el silencio, la soledad, la palabra, la autonomía; se encuentra la propia voz; se nos revela la esencia de nuestro decir, se rompe el cerco de nuestro conformismo y se gana altura. En la dialéctica con uno mismo, en ese perplejo anonimato, se dirime la libertad del individuo. Nadie nos otorga la libertad por más que se propague semejante desatino. Acaso la razón por la que los estudiantes se aferran a su escuela consiste en que hemos sabido comunicar una verdad antigua: poetizar es sagrado.

Antes que viaje estético, antes que experimentación con el lenguaje, la literatura es un fenómeno revelador. La aventura de la especie hizo posible la palabra. En todas las civilizaciones han existido visionarios llamados a consagrar en palabras sus visiones acerca de la verdad. El mundo es esencialmente misterioso, quien lo observa no demora en comprender que la realidad nos niega sus enigmas. Por eso los intentos más antiguos por revelar los misterios del mundo no fueron, como ahora, científicos sino sagrados, rituales. La palabra no se limitaba a comunicar o a representar; trascendía ese marco. La fuerza expresiva que rompe el velo sobre las cosas del mundo produce belleza. Distinguimos allí el origen sagrado de la palabra poética.

El sabio Robert Graves registra que en la Europa antigua, mediterránea y septentrional, la poesía era "un lenguaje mágico vinculado a ceremonias religiosas populares en honor de la diosa Luna, o Musa, algunas de las cuales datan de la época paleolítica, y que éste sigue siendo el lenguaje de la verdadera poesía, «verdadera» en el moderno sentido nostálgico de «el original inmejorable y no un sustituto sintético». Ese lenguaje fue corrompido al final del período minoico 
cuando invasores procedentes del Asia Central comenzaron a sustituir las instituciones matrilineales por las patrilineales y remodelaron o falsificaron los mitos para justificar los cambios sociales. Luego vinieron los primeros filósofos griegos, que se oponían firmemente a la poesía mágica porque amenazaba a su nueva religión de la lógica, y bajo su influencia se elaboró un lenguaje poético racional (ahora llamado clásico) en honor de su patrono Apolo, y lo impusieron al mundo como la última palabra respecto a la iluminación espiritual."

Hasta nuestros días ha subsistido y proliferado una poesía apolínea, dictada por el programa de la inteligencia, atenida a trucos retóricos, que reposa en el trono de terciopelo de la forma y que no se compromete con una coherencia cuyo torrente desemboque en la revelación conmovedora, esa que rompe la coraza del entendimiento $y$ deposita en el alma del que lee un mensaje significativo $y$ transformador.

Por eso mismo, hacer poesía es hacer sonar, tras las palabras, la palabra primigenia. ¿A qué imagen primigenia de lo inconsciente colectivo puede remitir la imagen desarrollada en la obra de arte?

La primera introgante a la que se ve enfrentado quien encara la enseñanza de la literatura es una elemental tentativa de delimitación. ¿Qué es lo literario? ¿Cómo establecer la diferencia entre la palabra artística y aquella que no lo es? ¿Sobre qué peculiaraidades se erige el discurso artístico?

El diccionario de la Real Academia Española define la literatura como "el arte que emplea como medio de expresión una lengua", mientas que a la palabra arte la define como la "manifestación de la actividad humana mediante la cual se expresa una visión personal y desinteresada que interpreta lo real o imaginado con recursos plásticos, lingüísticos o sonoros." Según estas orientaciones semánticas cualquier obra de representación, ya sea producto del intelecto o la emoción, 
contenida en un texto, puede ser considerada literaria. A mi entender, el asunto es mucho más complejo.

Partamos de la siguiente base. La sustancia del fenómeno literario es la palabra escrita puesta al servicio de la comunicación de lo esencial. El espíritu, en su permanente apetito de manifestación, se sirve de la sensibilidad y del intelecto del sujeto creador. Éste, fascinado por una incandescencia que Bachelard llama "ensoñación" invoca un discurso que apreciado por la conciencia lectora como portador de valores estéticos. Vencida la resistencia de la conciencia crítica, este mensaje bello comunica lo esencial y significativo, poniendo en el mundo una novedad: un producto de la imaginación que viene a sumarse al cúmulo de experiencias que constituyen lo real.

Resulta entonces que estamos ante una obra concebida por la razón, el conocimiento, la intuición y el sentimiento. Cuando esa suma de destrezas actúan de un modo coordinado, poniéndose al servicio de un discurso con valores artísticos, a eso podemos llamarlo talento. Dentro de la obra entonces se nos ofrece, más o menos evidente, una imagen y una música secreta. Esta imagen, al principio hospedada con emoción artística, luego es susceptible de ser analizada si la reconocemos como símbolo.

Así llegamos a una valoración que discrepa con las definiciones que fueron nuestro punto de partida. El escritor de literatura produce un arte que es de palabra sólo en apariencia y en el que las ideas tienen menos valor del que cabría suponer. Entendemos al escritor de poesía, al diseñador de poéticas más bien como un portador de imágenes que contienen la posibilidad de renovar el mito, lo primigenio.

Según Carl Gustav Jung, "hay obras, tanto en la poesía como en la prosa, que surgen enteramente de la voluntad y de la decisión del autor de producir tal efecto y no otro. En este caso, el autor somete a la materia a un tratamiento 
predeterminado y dirigido a un fin, restando y añadiendo a su antojo, subrayando este efecto, moderando aquél otro, poniendo aquí un color y allá otro, sopesando cuidadosamente los posibles resultados y respetando siempre las reglas de lo que se considera las formas bellas y el estilo. El autor emplea en este trabajo su juicio más agudo y elige sus expresiones con entera libertad. La materia es para él sólo materia sometida a su intención artística: quiere representar esto y no otra cosa. En esta actividad el poeta se identifica enteramente con el proceso creador, sin que importe si se ha puesto voluntariamente a la cabeza del impulso creador o si éste ha tomado posesión de él como mero instrumento hasta el punto de llegar a perder toda conciencia de tal hecho. Él es la creación misma y se encuentra inmerso en ella con todo su ser, inconfundibles ambos, con toda su intención y todo su saber.

"Hay otra clase de obras de arte que afluyen más o menos completas a la pluma del autor, que salen a la luz bien armadas, como Palas Atenea de la cabeza de Zeus. Estas obras se imponen literalmente al autor, toman posesión en cierto modo de su mano, su pluma escribe cosas que su espíritu contempla con asombro. La obra trae consigo su forma; lo que el autor quiere añadirle es rechazado, lo que él desdeña se le impone. Su consciencia contempla el fenómeno atónita y vacía, mientras se ve inundada por un torrente de ideas e imágenes que su intención jamás ha creado y que su voluntad jamás habría querido producir. Con renuencia tendrá que reconocer que en todo ello habla de sí-mismo, que su naturaleza más íntima se revela a sí misma y proclama en alta voz lo que él jamás le habría confiado a su lengua. Sólo puede obedecer y seguir ese impulso, aparentemente extraño a él, sintiendo que su obra es más grande que él, por lo que ejerce un dominio al que no puede oponerse. No es idéntico con el proceso de creación artística; es consciente de que se sitúa por debajo de su obra, o al menos a su lado, como una segunda persona que se viera abocada a girar en la órbita de una voluntad ajena a ella."

"Es en esto donde se identifica particularmente lo que hemos llamado "el genio", pues un espíritu especialmente dotado destaca precisamente porque, con 
toda la libertad y claridad de su "vivirse", se ve apremiado y determinado por lo incosciente, ese misterioso dios que habita en él, porque surgen en él visiones... sin que sepa de dónde proceden, porque se ve impelido a crear y actuar, sin que conozca su fin, y porque impera en él un impulso de llegar a ser y desarrollarse sin que sepa para qué".

"En consecuencia, la vida del escritor artista está necesariamente llena de conflictos, pues en él luchan dos fuerzas: el hombre común con sus justificadas reivindicaciones de felicidad, satisfacción y seguridad vital, por una parte, y por otra, la pasión despiadada y creadora que puede incluso dar al traste con todos sus deseos personales. De ahí que el destino vital personal de muchos artistas sea tan decididamente insatisfactorio, e incluso trágico... Rara vez un ser humano creativo no tiene que pagar cara la chispa divina de su grandiosa capacidad."

Es en este punto de incandescencia donde inicia la experiencia de enseñar a escribir. Mejor dicho: de acompañar el proceso de exploración interior que implica escribir literatura. En esta íntima encrucijada donde el autor comprende uando que está comunicando algo que es previo a las palabras y por lo tanto la escritura no se reduce a un asunto de corrección. Enseñar a escribir es también colaborar con él en la provocación de sus perplejidades, aunque este proceso sea incómodo y aún doloroso. Ensañar por enseñar.

En la obra de arte se cumple una revelación esencial mediante una forma estética. Lo estético entonces no es lo esencial sino el medio de acceso al mensaje significativo. La conciencia, siempre dispuesta a racionalizar su percepción del mundo, está acorazada por el intelecto. La operación estética es capaz de horadar esa armadura para que el mensaje ingrese y desove su materia transformadora. Dicho de otro modo, en el centro de la experiencia literaria no está la forma que adquiere el lenguaje que comunica, es decir, la sustancia, sino la revelación esencial a la que conduce ese lenguaje. 


\section{La palabra y la redención}

Según la suma de tradiciones mitológicas que ha nutrido la historia de la imaginación, el héroe, aquél que sintetiza y encarna valores admirables y deseables, nos da la libertad y recibe en justo pago la gloria. El castigo del antagonista es la culpa. Pero ¿dónde realmente reside el núcleo de la libertad individual? ¿Qué maniobra de la psique o del espíritu nos conduce a la toma de conciencia respecto a nuestra propia culpa, nuestra personal redención y nuestra individual gloria?

Dice Roberto Calasso que en los tiempos antiguos los hombres, que ya tenían asimilada la necesidad de ofrendar sacrificios a los dioses, sacrificaban frutos, pero no animales, a los que no usaban ni siquiera para alimentarse. Sopatro, un extranjero avecindado en Atenas, ofreció frutos y una torta a los dioses. En un descuido, un buey acometió el altar, devoró la torta y pisoteó inadvertidamente los frutos. Furioso, Sopatro arremetió a hachazos contra el animal, despedazándolo. Al poco rato, arrepentido, decidió exiliarse en Creta, sintiéndose culpable de impiedad. Instados por la Pitia, los atenienses acudieron a Sopatro y le solicitaron que volviera. Éste consideró que si todos compartían su acción, él se liberaría de la culpa. De manera que organizaron el sacrificio de un buey, al que mataron, despellejaron y cuya carne comieron. La culpa se colectivizó en un juicio al que acudieron todos los ciudadanos. Todo aquél que tuvo la palabra para justificarse, consiguió eludir que la culpa recayese en él. Así, las mujeres que llevaron el agua para afilar las armas culparon al afilador, el afilador culpó al hombre que blandió el hacha y el hombre del hacha culpó al hombre que usó el cuchillo para degollar al buey. En una sucesión de insólitos simbolismos, el hombre del degüello culpó al mismo cuchillo. Éste no pudo defenderse y fue declarado culpable. Desde entonces, se realizaron sacrificios de bueyes, sepultando con ello la anterior tradición. La conclusión es digna de destacarse: lo que nos salva de la culpa es la palabra. Quien no tiene voz, no se salva. 


\section{Juego y símbolo. De la palabra a la imagen}

En el territorio del texto literario hay un pacto entre dos conciencias soberanas: autor y lector. La fascinación y el juego presiden ese fenómeno en el cual la palabra media, funciona como puente, ya que la palabra literaria antes que ser comprendida pide ser experimentada. El juego hace posible la libertad y el signo conduce a lo esencial.

Y es precisamente este juego con las palabras el punto en donde un autor se llena de sentido, ya sea para contar una historia, para desplegar una sensibilidad o para abrazarse a una idea y alumbrarla. La buena literatura no se restringe a una operación narrativa, estética o intelectual. Existe, sí, la necesidad de esa aventura y el escritor se entrega a ella con ímpetu y cierto grado de compromiso. Pero la obra literaria es, ante todo, revelación. Propongo un ejemplo. En el cuento se busca articular un discurso en el que se conjuguen hechos narrados, formas ideales de narrar esos hechos y el excipiente necesario: un lenguaje espléndido por eficaz. Pero aún la presencia de estos tres hechos no garantiza el cumplimiento de la revelación. Todavía se precisa algo más, algo que no es una destreza. Es en todo caso una sensibilidad estimulada para lograr que el asunto narrativo de dicho cuento nos llegue cernido de significados y resonancias, que despida, en resumen, las incandescencias que lo hagan inolvidable.

La necesidad de escribir es una pulsión por desvelar el misterio del corazón del hombre. La obra terminada, la obra artística es una experiencia estética que espera su interlocutor; pero también es una invocación capaz de penetrar la bóveda del alma. Sabemos que el arte verdadero es indagación en el Enigma y que, llevada a su feliz extremo, la escritura literaria es una conmoción que conduce al sujeto a una revaloración de las más íntimas habitaciones de su ser. En consecuencia, aquél que se sueña o se pretende escritor verdadero no se contenta con una enunciación más o menos eficaz, correcta. Ambiciona -y su persecución 


\section{Revista Sul-Americana de Filosofia e Educação - RESAFE}

puede durar años - parir una verdad poética, una verdad estética, por medio de la invocación que es su obra. Debe entonces, ciertamente, pulir y calibrar amorosamente, las herramientas de su trabajo expresivo, desarrollar la fuerza de su decir. Eso significa encarar el necesario adiestramiento, el sacrificio del tiempo y el cumplimiento de un ritual de paso del cual ha de egresar sabiéndose escritor. Si la voluntad de escribir es una pulsión por revelar el Misterio, hacerlo significa construir una serie de artefactos verbales, igualmente misteriosos y fascinantes. Quiero decir, ser escritor es tener obra.

Cuando el autor se adiestra, ha de aprender a reconocer cuándo sus textos son ya una materia concluida, resuelta, y cuándo aún son atisbos, exploraciones que distan de alcanzar una calidad expresiva aceptable. Cuándo hay en su concepción facilismo, falta de rigor, superficialidad, ingenuidad y un régimen de lugares comunes. Para ser de veras escritor, se deberá preparar seriamente; leer a los grandes, aprender de ellos; reflexionar acerca de sus emociones, pero las más esenciales, sus abismos, no la superficie que lleva a enunciar bisutería o a confeccionar anécdotas, sino ser visitado por visiones que lo conducen a expresar verdades como nadie más podría expresarlas.

El camino no es corto ni es fácil. El escritor en ciernes deberá comprender que un rito de paso no enseña sino que hace significativo el tránsito de un estado de su conciencia a otro completamente nuevo y acaso todavía inhabitable. Un tránsito donde una parte del individuo debe morir simbólicamente para que una nueva pueda nacer. Morirá, no sin amargura ni sin agonía, la confortable paz de la autocomplacencia. Sobrevendrá la noche con su miedo al descenso. La dolorosa crítica violentará su aplomo. Mirará su magra desnudez, su inopia técnica. Percibirá una ingenuidad que antes no era evidente. Netenderá que son suyas las imperfecciones que antes consideraba ajenas.

Pero es el único camino. Le será de ayuda asociarse con otros escritores, consagrados e incipientes, y ha de preferir el despiadado juicio de los maestros sobre el aplauso fácil de los aficionados. Se mostrará autocrítico y humilde pero a 


\section{Revista Sul-Americana de Filosofia e Educação - RESAFE}

la vez irá conquistando la confianza en su talento. No debería apresurarse en alcanzar el reconocimiento. Si es capaz de admitir que la fase en la que se encuentra su trabajo es embrionaria, sospechará también que es indispensable permitir que los embriones alcancen su completo desarrollo antes de ver la luz. Cuando eso ocurra, el ritual se habrá cumplido. El creador podrá sentirse orgulloso de haber ingresado inequívocamente, más que a un gremio o un grupo, a una tradición: la de los escritores verdaderos.

Opino con Conolly que un gran escritor contiene la mezcla del interés por la dignidad humana y el desprecio por ella, que además de poseer un gran sentido de perfección, comprende la esencia de la condición humana y su proximidad al Abismo, y que su vida tiene valor en la medida en que contribuye al enriquecimiento y la emancipación de espíritu, ya que la literatura, además de fuerza creadora, conduce a la expansión de la conciencia. En su desenvolvimiento multiforme, produce la sustancia medular que es el componente largamente solicitado: el espejo de la identidad colectiva a partir de la gesta creativa individual.a honestidad del creador consiste en mirar su grandeza y su tragedia en el espejo refulgente de la literatura.

No hay enseñanza posible. Las búsquedas individuales no se pueden transplantar.

Queda el asombro. El mundo no puede decirse. Hay que dejarse asombrar por el mundo. Resignarse a ser instante pero vivir como si se pretendiera ir más allá de el instante.

Eso queda. En el afán por provocar, incomodar, suscitar exploraciones, se erige una poética personal del encuentro y el talento se sacrifica en un altar mayor. Es decir, se encuentra la propia poética para habitar el encuentro con el que busca pronunciarse. Nos conmovemos con él porque su búsqueda es hermosa y lamentable. Es un balbuceo, como quien busca en su memoria, sin éxito, la frase 
que lo explica. Esa es mi sencilla contribución al acto de mirar, desde dentro, el fenómeno poético. Comparto, de salida, una de sus ventanas.

Descorro las cortinas para habitar la luz

Su inclemencia profana los cantos de los libros.

El polvo brota desafiendo al ojo

El rumor de la calle entra y devasta el secreto de la tarde

Busco la frase

en la explanada blanca de las páginas

La he perdido

y la preciso con una sed de árbol

Un libro la contiene

En esta habitación en este idioma

pero es remota

Cae polvo

lo miro

y sobre la mirada cae más polvo

Con su luz inequívoca

otras frases vendrán antes del sol

No serán la que busco

Bien está

La oscuridad se cierne como un ave de sombras 